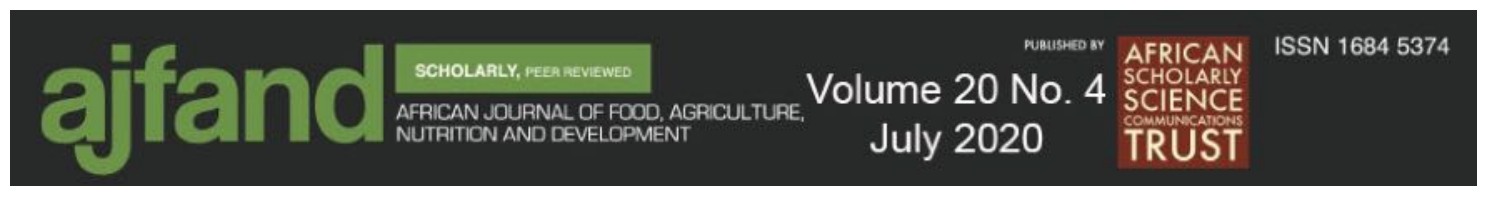

Afr. J. Food Agric. Nutr. Dev. 2020; 20(4): 16143-16160 $\quad$ https://doi.org/10.18697/ajfand.92.18225

\title{
POLYCYCLIC AROMATIC HYDROCARBON CONTENT IN SAUSAGE SMOKED USING A POLISH TRADITIONAL METHOD
}

Choroszy $\mathbf{K}^{1 *}$ and $\mathbf{K}$ Tereszkiewicz ${ }^{1}$

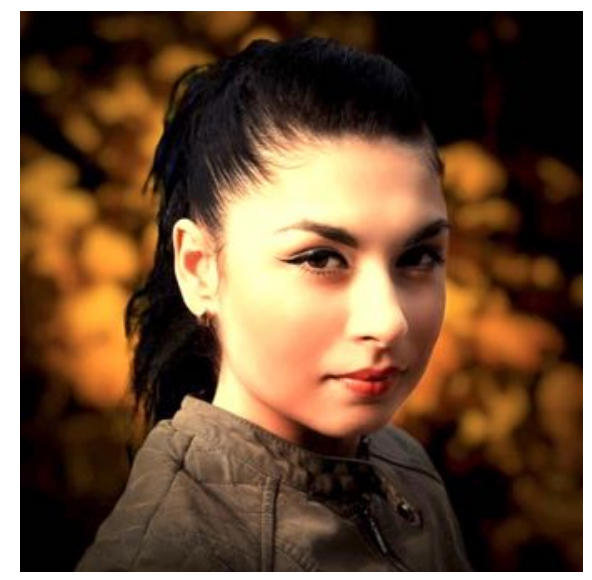

Karolina Choroszy

*Corresponding author email: choroszy@prz.edu.pl

${ }^{1}$ Rzeszów University of Technology, The Faculty of Management, Department of Computer Engineering in Management, Powstańców Warszawy 8, 35-959 Rzeszów, Poland 


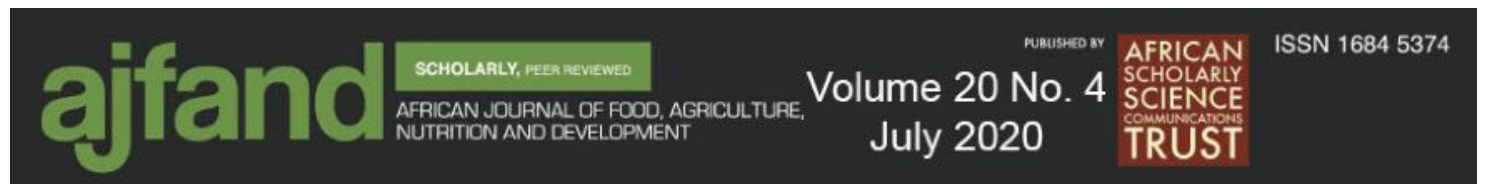

\begin{abstract}
Smoking is one of the oldest and most frequently used methods of preserving meat and its products. In Poland, smoking using a traditional method is still a commonly practised form of preserving meat products. It is conducted in smoking chambers, using a process in which the hardwood of deciduous trees with the level of humidity between $10 \%$ and $30 \%$ is burnt as the source of smoke and heat. The aim of this research was to assess the impact of selected polycyclic aromatic hydrocarbons (PAHs) on traditionally smoked sausage, a cured meat product. The presence of PAHs in the environment and food products is undesirable due to their proven carcinogenic, mutagenic and teratogenic properties. In the present study, the level of four PAHs, which included benzo(a)pyrene, chrysene, benzo(a)antracene and benzo(b)fluoranthene, was measured using highperformance liquid chromatography. The temperature in the furnace was maintained between 600 and $850^{\circ} \mathrm{C}$. The duration of smoking was varied $-4-5,5-6,6-7$ and 7-8 hours. Results showed that the time span of traditional smoking influences the products' benzo(a)pyrene, benzo(a)antracene and benzo(b)fluoranthine contamination levels. The concentration of PAHs in products with the smoking time of 6-7 and 7-8 hours was higher than the concentration observed in products with a shorter smoking time. The changes in the sum of the concentrations of the four analysed PAHs resulted from the changes in the concentration of each hydrocarbon separately. Benzo(a)anthracene content was within the range of 11.17 and $14.19 \mu \mathrm{g} / \mathrm{kg}$ while the content of benzo(a)pyrene was between 4.15 and $7.69 \mu \mathrm{g} / \mathrm{kg}$. The average value of benzo(b)fluoranthene was between 4.99 and $7.75 \mu \mathrm{g} / \mathrm{kg}$. Chrysene contamination was within the range of 9.85 and $10.77 \mu \mathrm{g} / \mathrm{kg}$. Moreover, it was found that the aggregate content of the analysed PAHs significantly exceeds the limits specified in European Union regulations. Since September 1, 2014, the limits were decreased to $2.0 \mu \mathrm{g} / \mathrm{kg}$ (benzo(a)pyrene) and $12.0 \mu \mathrm{g} / \mathrm{kg}$ (sum of four PAHs), respectively. The results suggest that the prolonged smoking process conducted in high temperature may be an impediment to approving the examined products for marketing.
\end{abstract}

Key words: smoking, food, safety, PAHs, quality management, smoking time, traditional smoking 


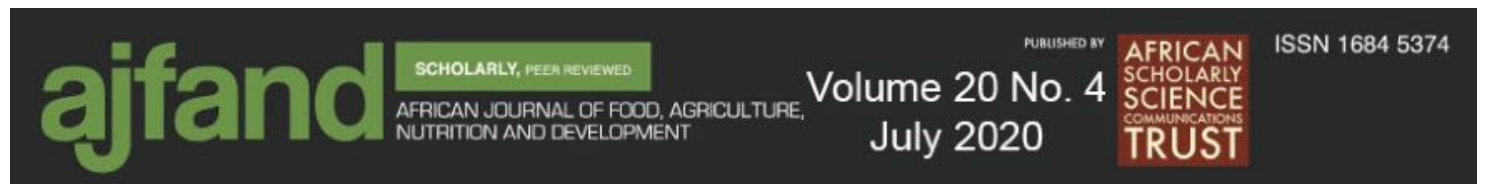

\section{INTRODUCTION}

Smoking is one of the oldest and most frequently used methods of preserving meat and its products $[1,2,3]$. Traditional smoking is still a widely popular method of preserving meat products in Poland. It is conducted in smoking chambers, using a process in which the hardwood of deciduous trees with the level of humidity between $10 \%$ and $30 \%$ is burnt as the source of smoke and heat $[4,5]$. The processed products are located on rods above or at a certain distance from the furnace in which the wood is burnt $[4,5,6,7]$. The smoke is produced with variable access of atmospheric oxygen. The most frequently used types of wood include alder, beech and cherry $[4,8]$. The smoke obtained in this process is a multicomponent mixture of water vapour, air and the compounds resulting from the process of wood pyrolysis. According to multiple sources, the smoke may contain more than 1000 varying chemical compounds $[4,8,9,10,11]$. The smoke composition depends on the type and chemical composition of the wood, its humidity, the combustion temperature, as well as the atmospheric conditions inside and outside of the smoking chamber $[12,13,14,15]$.

The smoke may contain substances which may be dangerous to consumers after the consumption of contaminated products $[4,8,9,10,11,16]$. Polycyclic aromatic hydrocarbons (PAHs) are a group of about 10,000 compounds comprised of fused aromatic rings without hetero-atoms or carry substituents, a few of which occur in considerable amounts in the environment and in food. Polycyclic aromatic hydrocarbons containing up to four fused benzene rings are known as light PAHs, while those containing more than four benzene rings are called heavy PAHs. Heavy PAHs are more stable and more toxic than light ones. Polycyclic aromatic hydrocarbons are lipophilic in nature, though some of them can dissolve fairly well in water $[15,16]$. This group includes polycyclic aromatic hydrocarbons (PAHs) $[6,17,18]$. The presence of PAHs in the environment and food products is undesirable due to their proven carcinogenic, mutagenic and teratogenic properties [9, 19, 20, 21, 22, 23, 24]. According to numerous authors, besides smoking, PAHs are created during the processes of drying, frying, roasting and barbecuing meat and its products $[1,21,25,26,27,28,29,30,31]$. The aim of this research was to assess the impact of selected PAHs on traditionally smoked sausage, a cured meat product.

\section{MATERIALS AND METHODS}

\section{Sausage Samples}

The analysed material was "Traditionally smoked sausage", produced in four selected meat processing companies located in South-Eastern Poland. The samples for PAH content analysis were drawn directly from the products after thermal processing, adjustment to the ambient temperature and packing, according to the PN-EN ISO 15753 regulation (Vegetable and animal oils and fats - Determination of polycyclic aromatic hydrocarbons). The material for the study comprised 20 samples of "Traditionally smoked sausage". The weight of a single sample was approximately $1.5 \mathrm{~kg}$. 


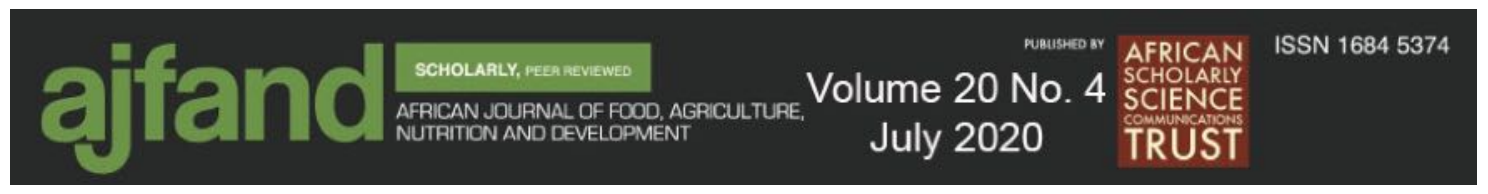

The composition of the examined "Traditionally smoked sausage" complied with the specification provided by the producer. The essential composition of the sausage was as follows: Class I "warm" pork meat from the shoulder, warm pork jowls (40\%), and pork skins (10\%). Additional ingredients comprised spices constituting $5 \%$ of the mass of the product. The spices included evaporated salt, pepper, garlic, sugar, and water. The sausages were packed in natural casings.

The samples of the sausage were collected immediately after completion of the smoking process in the production company, placed in sterile containers and hermetically sealed under the supervision of an employee of the quality control department. The material was then transported under refrigeration to the laboratory within 45 minutes.

The material was minced using a T10 basic IKA laboratory homogeniser. Samples of approximately $20 \mathrm{~g}$ were obtained from the homogenate. The samples were packaged into sterile glass receptacles and frozen at a temperature of $-25^{\circ} \mathrm{C}$.

The sausage was produced in the following stages: mixing in a vacuum mixer for 20-30 minutes, stuffing with piston stuffer without vacuum, then hanging on smoking trolleys, embedding in front of a natural (grate) smokehouse, which lasted about 3 hours, and smoking. After thermal processing was completed, the product remained in the smoke chamber to allow autogenic adjustment to the ambient temperature. The sausage was then cooled to a temperature of $+8-10^{\circ} \mathrm{C}$ and vacuum-packed.

The process of smoking was conducted by generating smoke in the furnace located approximately $50 \mathrm{~cm}$ from the smoking chamber, and both were connected with each other by an intake manifold. The smoke was generated by the pyrolysis of air-dried beech chips and pieces. Subsequently, low-boiling substances, consisting mostly of volatile compounds, were directed to the smoking chamber. The process of incandescent burning in the furnace allowed the temperature to be sustained between $600^{\circ} \mathrm{C}$ and $850^{\circ} \mathrm{C}$. The temperature of the furnace was measured with an LB-707 thermometer - barometer hygrometer. The smoking time span varied and was 4-5, 5-6, 6-7 and 7-8 hours in each of the examined companies. The process of smoking was divided into two parts: initially, smoking was combined with drying at a temperature of $75^{\circ} \mathrm{C}$, and secondly, smoking was conducted with concurrent roasting at a temperature of $80-85^{\circ} \mathrm{C}$.

It is not possible to determine the exact time of each stage, because traditional smoking is a specific process. The whole process was supervised directly by an employee with long-term experience in smoking. The duration of each phase of smoking was determined by means of sensory evaluation performed by the person supervising the process. The evaluation involved an assessment of the general appearance, colour and texture of the product. Moreover, the following rule was observed in all the plants: $70 \%$ of the total smoking time comprised smoking and drying, and 30\% involved smoking and roasting.

\section{Determination of PAH content}

The polycyclic aromatic hydrocarbon $(\mathrm{PAH})$ content was determined with the use of HPLC method. The study examined the level of contamination with four PAHs [National Institute of Public Health - National Institute of Hygiene], which are considered to be 


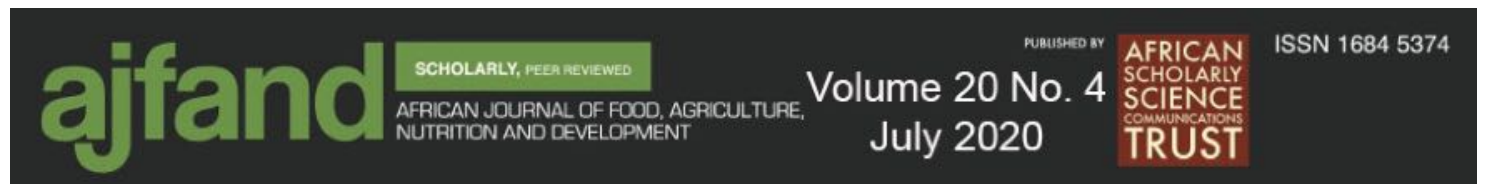

dominantly present in food products: benzo(a)pyrene, chrysene, benzo(a) antracene, benzo (b) fluoranthene.

The determination of PAH content was conducted by extracting the fat fraction from the surplus weight of the product using the Soxhlet extraction method. The process was conducted with the use of a $100 \mathrm{~cm}^{3}$ capacity apparatus and solvent hexane + DiChloroMethane in a ratio of $3+1(\mathrm{v} / \mathrm{v})$ over a period of 8 hours. After the extraction process was completed, the fat fraction obtained was purified using two different methods. The concentrated sample was purified using SEC/GPC exclusion chromatography. Bio-Beads SX-3 beads were used in the column with the dimension of $50 \mathrm{~cm} \times 1.5 \mathrm{~cm}$. The employed solvent was a mixture of cyclohexane and ethyl acetate in a 1:1 ratio (volume proportion). The fluxion was $2 \mathrm{~cm}^{3} / \mathrm{min}$. The preliminary fraction with the volume of $60 \mathrm{~cm}^{3}$ was discarded. The next fraction of $60 \mathrm{~cm}^{3}$, containing PAHs, was collected. This sample was concentrated and purified by means of the solid phase extraction method (SPE), with SPE column of $6 \mathrm{~cm}^{3}$ volume containing $1000 \mathrm{mg}$ of silica gel. The column was conditioned by a mixture of hexane and dichloromethane $1+1(\mathrm{v} / \mathrm{v})$, then a sample of $3 \times 1 \mathrm{~cm}^{3}$ was deposited and a sample of $2 \times 5 \mathrm{~cm}^{3}$ was eluted. The final fraction of $8 \mathrm{~cm}^{3}$ was concentrated.

Following purification, the sample underwent qualitative and quantitative analysis of PAH content using liquid chromatography. Waters Alliance 2695 with the column Agilent PAH 5 Pursuit C18 with the dimension of 250x4.6 $\mathrm{mm}$ and $5 \mu \mathrm{m}$ high pressure liquid chromatography analyser was used in the process. Samples of $50 \mu 1$ were dosed; the column temperature was $30^{\circ} \mathrm{C}$. The mobile phase flow speed was $1 \mathrm{~cm}^{3} / \mathrm{min}$. The gradient program is presented in Table 1.

The analysis was conducted in compliance with the AS-BbC - 05.05.15 internal standards. The identification of PAHs was conducted with a fluorescence detector with excitation and emission wave programming, presented in Table 2.

The polycyclic aromatic hydrocarbon (PAH) content in $\mu \mathrm{g} / \mathrm{kg}$ of a sample was indicated using the 15WWAv2 program. Polycyclic aromatic hydrocarbon content was calculated using external calibration for each compound with internal standard addition, which also added to the subsequent samples before the extraction step. Results are corrected by recovery.

\section{Statistical analysis}

Analysis of variance (ANOVA) (test F) and Tukey test were used to verify the hypothesis that the concentration of PAH is dependent on the time span of smoking. The level of significance $=0.05$ was indicated in the verification. Statistica 12 software was used to verify the hypothesis. 


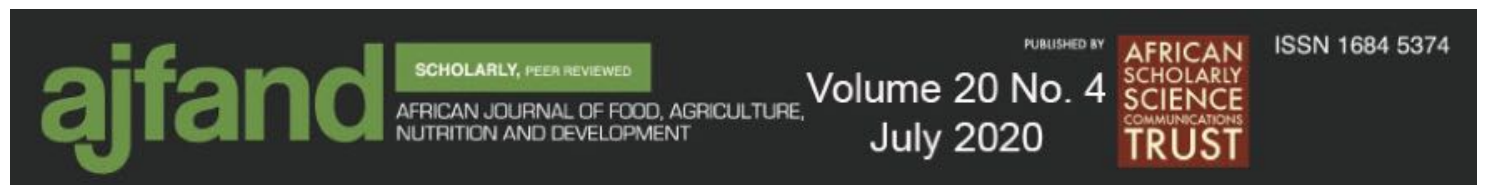

\section{RESULTS AND DISCUSSION}

Figures 1-5 present the arithmetic mean and standard deviation values of the PAH content and their sums in "Traditionally smoked sausage", depending on the smoking time span. Table 3 shows percentage changes of the analysed PAH content in various time spans.

Polycyclic Aromatic Hydrocarbons (PAH) content in "Traditionally smoked sausage" The data indicate that the smoking time span has a statistically significant impact on the concentration of benzo(a)anthracene, benzo(a)pyrene and benzo(b)fluoranthene. The content of these hydrocarbons was considerably higher in the product smoked in 6-7 hours and 7-8 hours. The most significant change of benzo(a)anthracene concentration was observed between the product smoked in 4-5 hours and the one smoked in 6-7 hours. It is noteworthy that the sum of the analysed PAHs increased with time. On the basis of the analysis of the changes of each PAH content, it was found that benzo(a)anthracene content was within the range of 11.17 and $14.19 \mu \mathrm{g} / \mathrm{kg}$ (SD in the range between 1.76 and $2.03 \mu \mathrm{g} / \mathrm{kg}$, Fig. 1) and independently of the smoking time span was characterised by a similar variability (Table 3 ), which constitutes between $14.30 \%$ and $15.70 \%$ of the arithmetic mean. The study indicated an essential influence of the smoking time span on the concentration of benzo(a)anthracene in the analysed products. It proved that the concentration of benzo(a)anthracene increased with the increase in the smoking time span up to 6-7 hours. In the product processed for 7-8 hours, the contamination level was fractionally decreased in comparison to the sausage smoked for 6-7 hours, contrary to an earlier observation that it increases with time.

According to previous research [25], the smoking time span has a crucial influence on the concentration of each PAH. The authors state that benzo(a)anthracene content increases from $0.05 \mu \mathrm{g} / \mathrm{kg}$ to $2.94 \mu \mathrm{g} / \mathrm{kg}$ in the meat products smoked for 10 hours. These figures are smaller than the ones observed in the present study. However, the difference may be caused by distinct temperatures during the curing processes.

In two Spanish products, "Androlla" and "Botillo", benzo(a)anthracene contamination level was considerably low - on average $0.67 \mu \mathrm{g} / \mathrm{kg}$ ("Androlla") and $0.51 \mu \mathrm{g} / \mathrm{kg}$ ("Botillo"). "Androlla" was smoked for 8-10 days, and "Botillo" was smoked for 7-15 days [3]. The research conducted by German scientists [38, 39] on the contamination of two types of frankfurter sausage and salami processed industrially indicated a relatively low level of PAH contamination in comparison to the present research. The benzo(a)anthracene content was within the range of $0.82 \mu \mathrm{g} / \mathrm{kg}$ and $2.06 \mu \mathrm{g} / \mathrm{kg}$. The sum of four PAHs in frankfurter sausages equalled $3.35 \mu \mathrm{g} / \mathrm{kg}$ on average and in salami the same parameter equalled $3.2 \mu \mathrm{g} / \mathrm{kg}$. However, the analysed products in the aforementioned research were processed using cold smoking. The comparison of the results of the present research and the quoted data implies that the temperature of the smoking process is, along with the smoking time span, a factor determining the level of contamination of the analysed products with PAHs. 

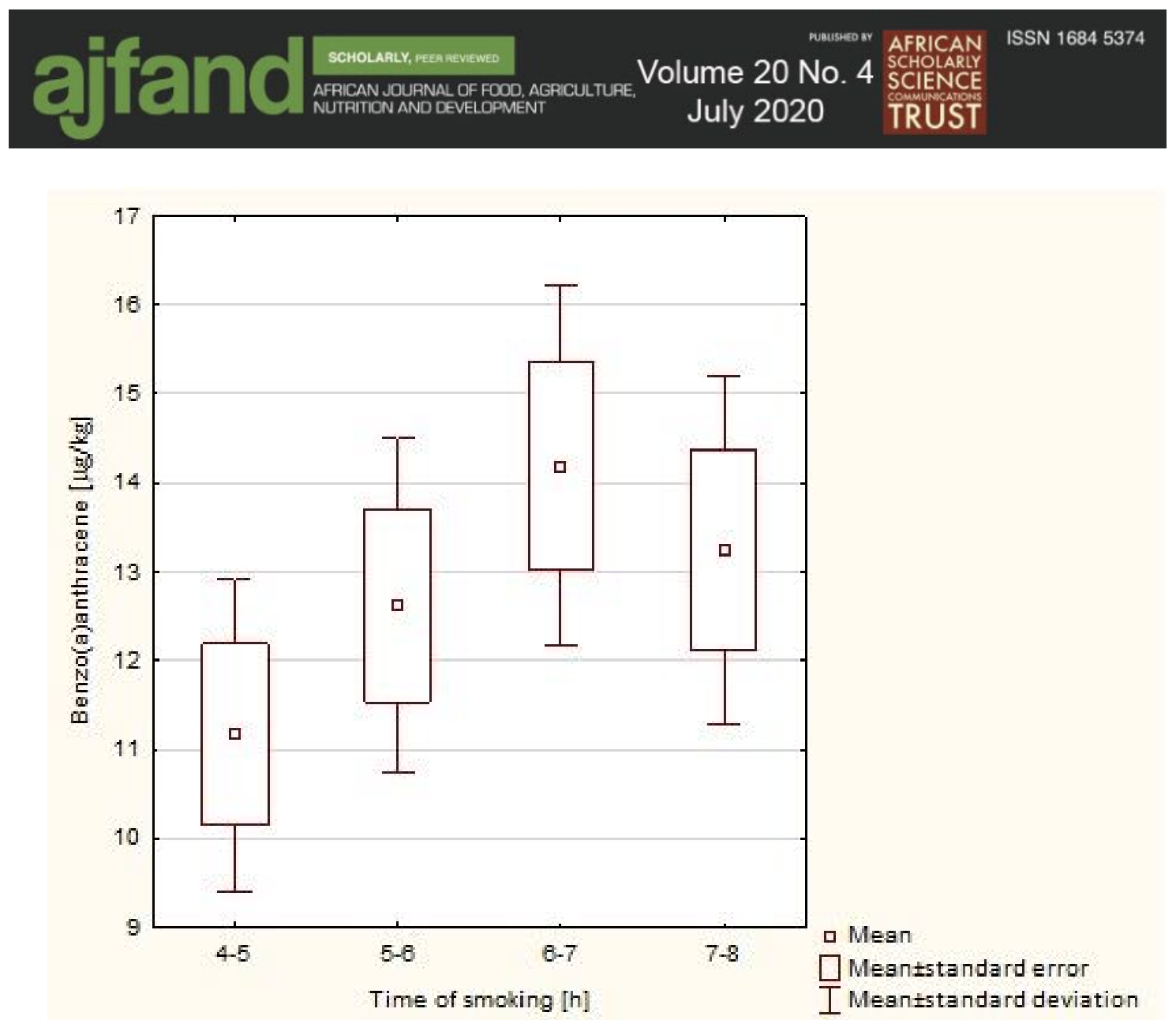

․ Mean

$\square$ Meantstandard error I Meantstandard deviation

Figure 1: Benzo(a)anthracene content in "Traditionally smoked sausage" depending on the smoking time span

The average content of benzo(a)pyrene varied depending on the smoking time span and was within the range of 4.15 and $7.69 \mu \mathrm{g} / \mathrm{kg}$ (Fig. 2.). The intra-object variation in the changes of the concentration of this PAH was insignificant. Tukey test and the chart indicated in Figure 2 show that benzo(a)pyrene content in the product increases with the increase in the smoking time span. In the product smoked for 4-6 hours; the content of benzo(a)pyrene equalled 4.2-4.3 $\mu \mathrm{g} / \mathrm{kg}$; the smoking time span of 6-7 hours increased the content level above $5 \mu \mathrm{g} / \mathrm{kg}$; in the product smoked for up to 8 hours the content was at the level of $7.69 \mu \mathrm{g} / \mathrm{kg}$. The highest benzo(a)pyrene contamination level was observed in the product with a smoking time span of 7-8 hours and it was statistically significantly $(p<0,05)$ higher in comparison to the products with a shorter smoking time span. Furthermore, inconsiderably lower concentration of benzo(a)pyrene in the product smoked for 5-6 hours compared to its concentration in the sausage smoked for 4-5 hours was observed (Fig. 2.).

The research concerning the influence of the smoking time span on the contamination of meat products with benzo(a)pyrene has been conducted by other authors as well $[14,40]$. The studies [25] indicate that the smoking time span has a significant impact on the concentration of benzo(a)pyrene in smoked meat products. The benzo(a)pyrene content in smoked ham after 12 days of the smoking process was $0.2 \mu \mathrm{g} / \mathrm{kg}$, and after 15 days it increased to over $0.5 \mu \mathrm{g} / \mathrm{kg}$. A significant increase in the benzo(a)pyrene content in beef 


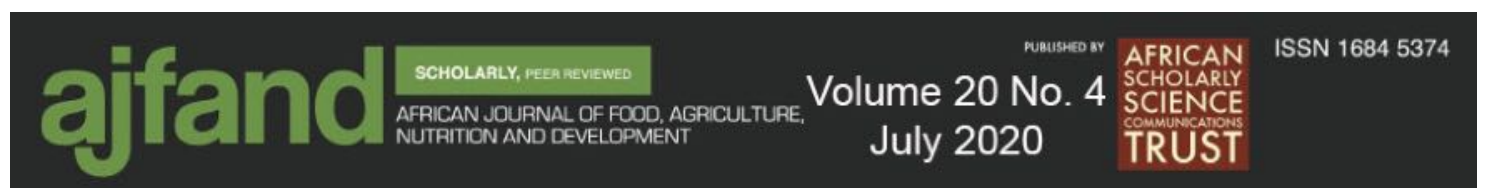

ham was observed between the 1st and 18th day of the smoking process - from 0.02 $\mu \mathrm{g} / \mathrm{kg}$ to $1.1 \mu \mathrm{g} / \mathrm{kg}$.

The results imply that the concentration of benzo(a)pyrene in all analysed samples significantly exceeds the level of $2 \mu \mathrm{g} / \mathrm{kg}$, which is the maximum acceptable level indicated by the European Commission [36].

An excessive benzo(a)pyrene contamination of chorizo was identified by Fasano et al. [11]. The average contamination level was $132 \mu \mathrm{g} / \mathrm{kg}$, and the analysis of one of the samples indicated $552 \mu \mathrm{g} / \mathrm{kg}$ of benzo(a)pyrene. The content of this hydrocarbon in the same type of meat product was analysed by Ledesma et al. [40] as well. The average content equalled $1.6 \mu \mathrm{g} / \mathrm{kg}$, which is below the "new" limit; however, the contamination level in five of the analysed samples exceeded the limit, similarly to the results of the present research. The results exceeding the limits were observed in the research by Migdał et al. [41] - in the analysed snack stick sausages the content of benzo(a)pyrene was at the level of $9.1 \mu \mathrm{g} / \mathrm{kg}$ [41]. The high contamination level may be related to a large absorbent surface, small section and low water content. One of the major aims of smoking meat products is reducing water content, as well as preserving the product and increasing its microbiological safety. According to Ledesma et al. [40], this may result in an increase in benzo(a)pyrene content in dried products, which was proven by the example of the analysis of chorizo [40].

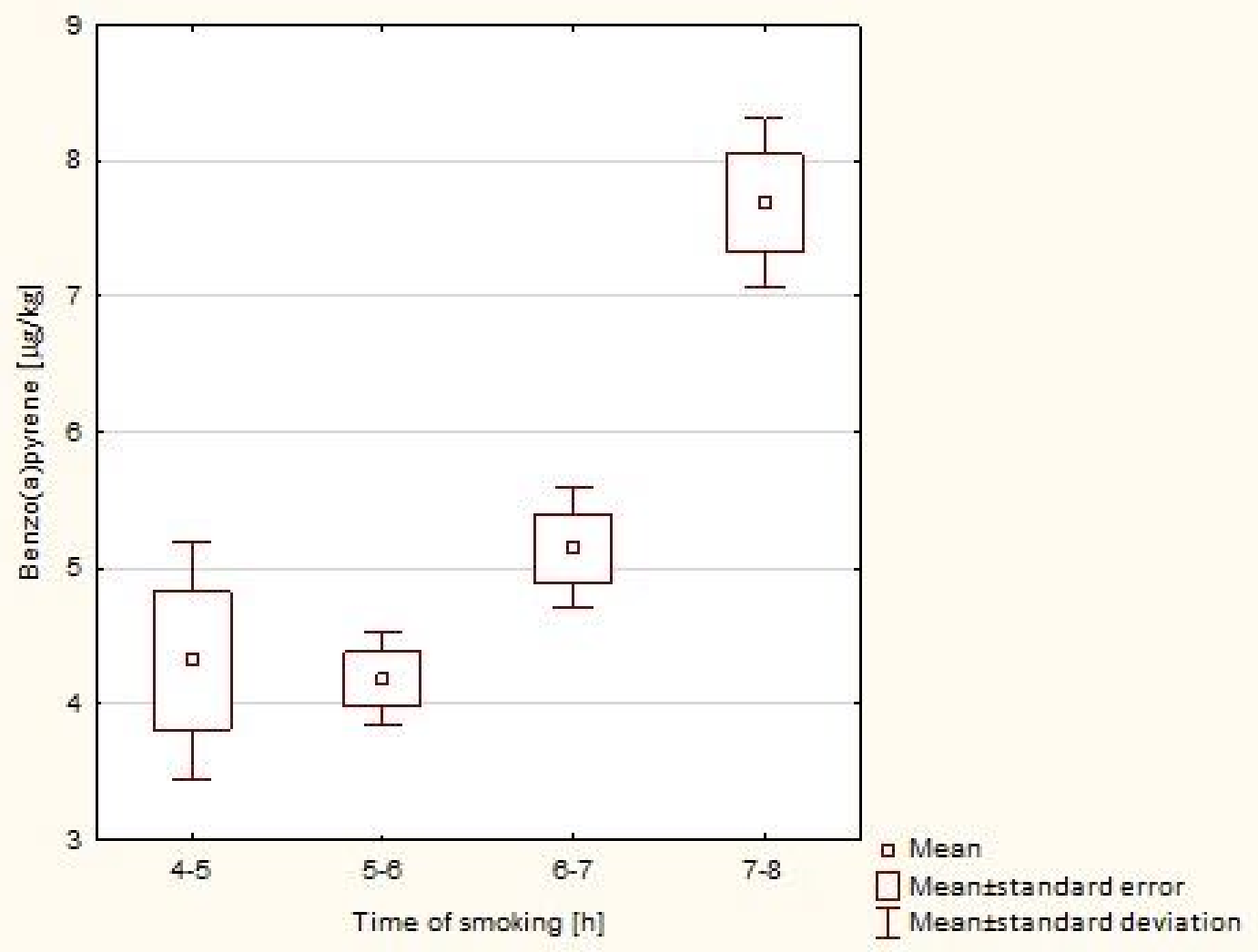

Figure 2: Benzo(a)pyrene content in "Traditionally smoked sausage" depending on the smoking time span 


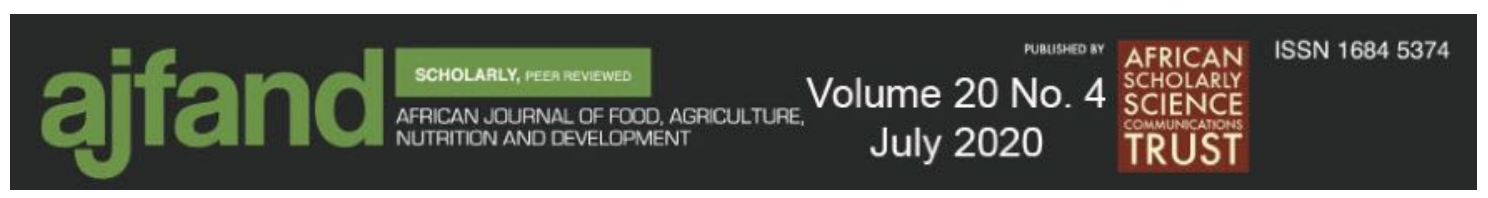

In the present studies, the content of benzo(b)fluoranthene (Fig. 3.) was indicated - the average value was between $4.99 \mu \mathrm{g} / \mathrm{kg}$ (in the smoking time span of 5-6 hours) and 7.75 $\mu \mathrm{g} / \mathrm{kg}$ (in the smoking time span of 7-8 hours). Standard deviation was in the range of 0.68 and $0.98 \mu \mathrm{g} / \mathrm{kg}$, which constituted $13-16 \%$ of the average in each group. The post hoc analysis indicates that the concentration of benzo(b)fluoranthene in "Traditionally smoked sausage" was not dependent on the smoking time span and was within the range of 4.99 and $5.50 \mu \mathrm{g} / \mathrm{kg}$. The statistical analysis proved that benzo(b)fluoranthene contamination was significantly higher in the product with the longest smoking time span in comparison to the other products. The contamination of the product smoked for 7-8 hours was approximately $18 \%$ higher than the contamination of the product with the smoking time of 4-5 hours.

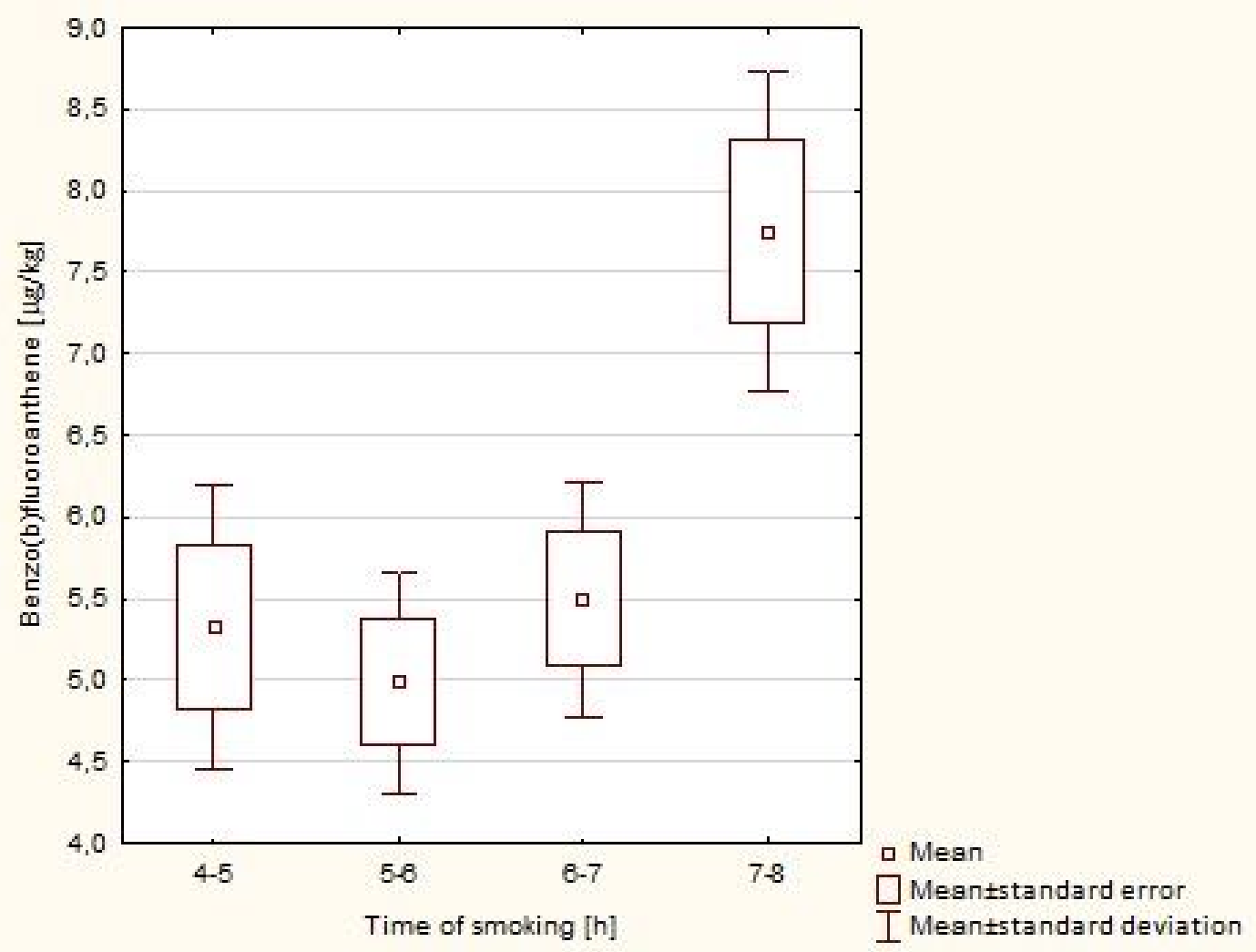

Figure 3: Benzo(b)fluoranthene content in "Traditionally smoked sausage" depending on the smoking time span 

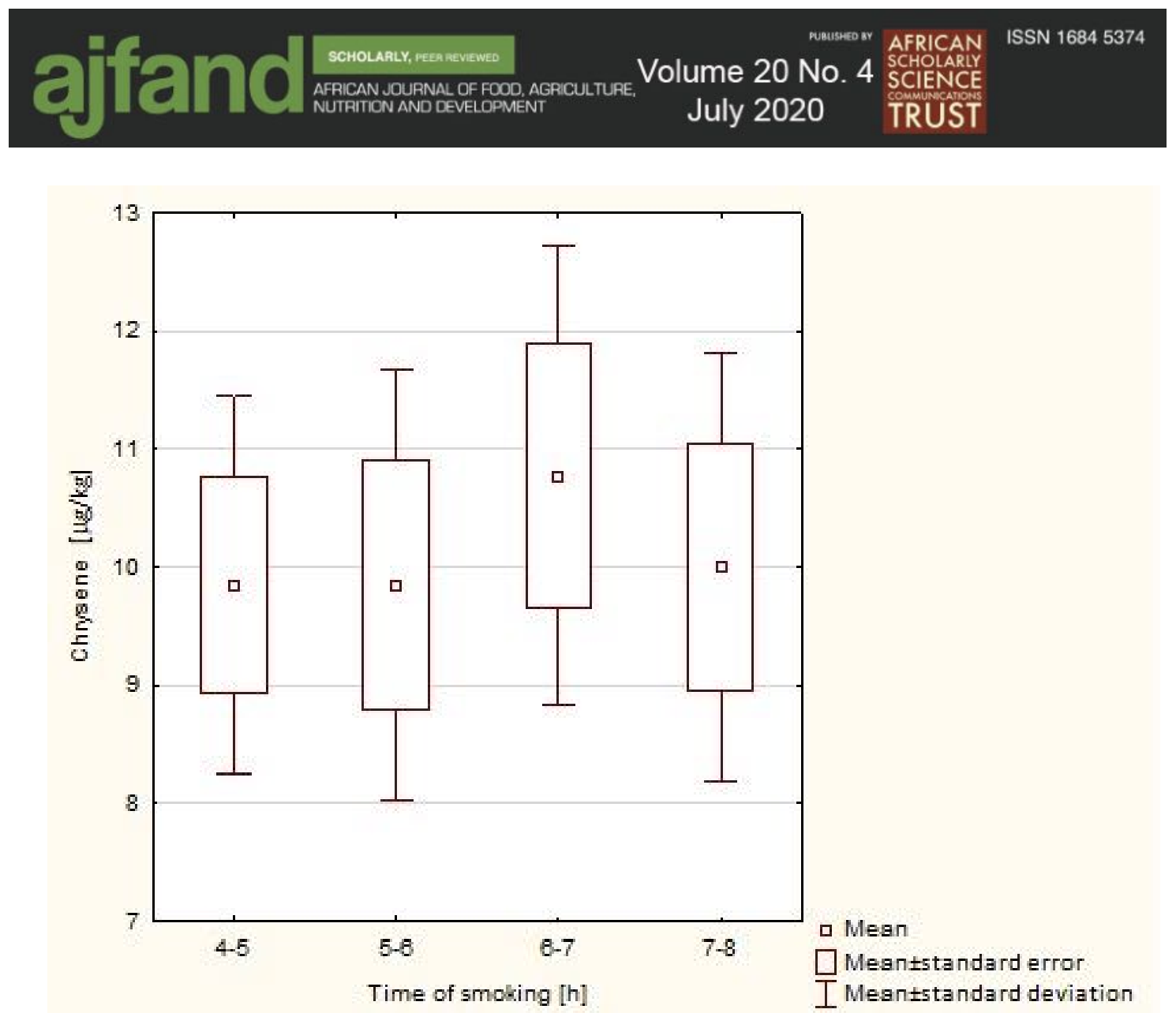

Figure 4: Chrysene content in "Traditionally smoked sausage" depending on the smoking time span

Numerous studies [15, 28, 29] demonstrate that among the PAHs limited by the European regulations, chrysene is a PAH encountered in the highest concentration in cured meat products. This observation was confirmed by the present research as well.

The data presented in Figure 4 implies that the average chrysene contamination was within the range of 9.85 and $10.77 \mu \mathrm{g} / \mathrm{kg}$. However, the statistical analysis showed no influence ( $p>0,05)$ of the smoking time span on the content of chrysene in the examined products (for the smoking time span between 4 and 8 hours). Due to the proven toxicity of this compound [19, 20,21, 22, 23,24, 9], its excessive concentration in the analysed products may pose a major threat to the health of the consumer.

According to Fasano et al. [11], the contamination of the analysed samples with chrysene was within the range of 21 and $649 \mu \mathrm{g} / \mathrm{kg}$, which significantly exceeds the results of the present research. Similarly, Lorenzo et al. [3] identified an excessive chrysene contamination level in a number of analysed samples (for example, $12 \mu \mathrm{g} / \mathrm{kg}$ in "Chorizo de cebolla"). However, another author identified a relatively low contamination level in "Botillo" and "Androlla" sausages - approximately $1 \mu \mathrm{g} / \mathrm{kg}$ on average in both products.

\section{The sum of four PAHs in "Traditionally smoked sausage"}

Currently, the sum of the concentrations of four PAHs is a crucial criterion for approving the traditionally smoked meat products for marketing. The maximum acceptable 


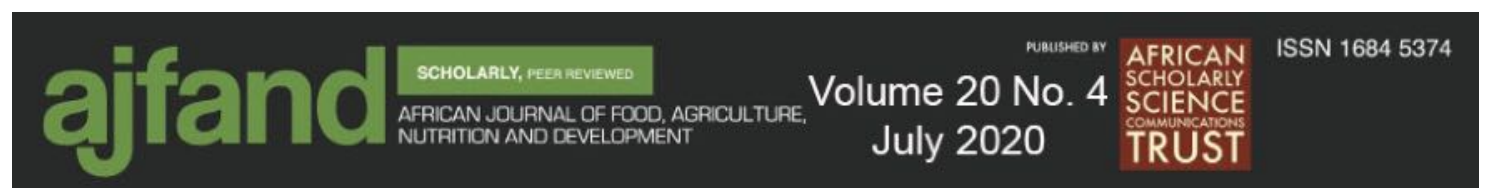

contamination level of the products with the sum of all four PAHs (indicated by the regulations of the European Commission) is $12 \mu \mathrm{g} / \mathrm{kg}$.

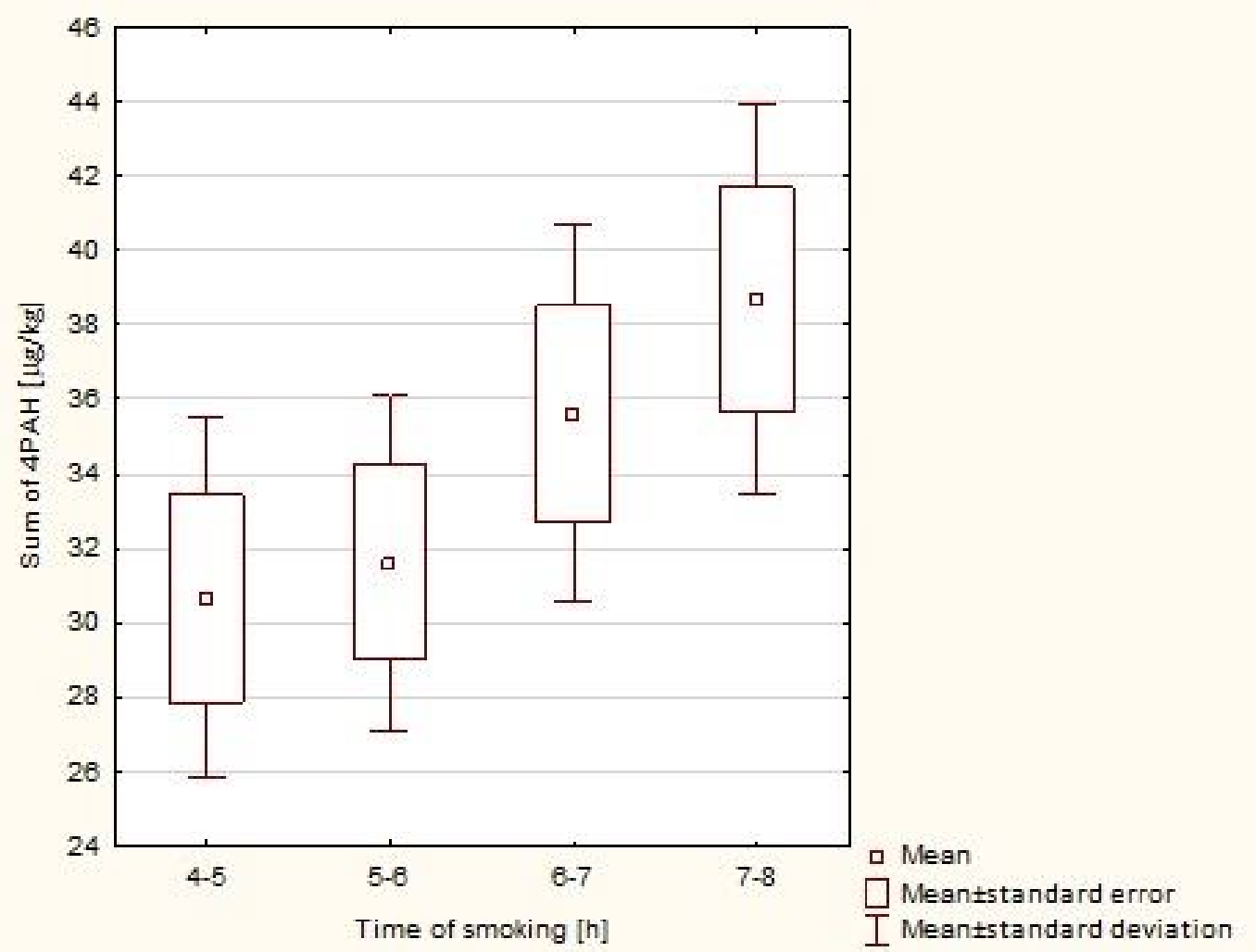

Figure 5: The sum of four PAHs in "Traditionally smoked sausage" depending on the smoking time span

The present research showed that the contamination level was approximately three times higher than the maximum limit. This implies that the use of prolonged smoking process in high temperature in the production of "Traditionally smoked sausage" may pose a crucial impediment to approving the product for marketing. The high PAH content was determined primarily by the high concentration of benzo(a)anthracene and chrysene. The present research showed an increase in the PAH aggregate concentration depending on the increase in the smoking time span (Fig. 5). In the product with the shortest smoking time span the sum of four PAHs equalled $30.66 \mu \mathrm{g} / \mathrm{kg}$, and in the product smoked for 78 hours it was $38.67 \mu \mathrm{g} / \mathrm{kg}$. This increase is statistically significant $(\mathrm{p}<0.05)$. The most significant increase in the concentration of four PAHs was caused by exceeding the smoking time span over 6 hours.

Other studies have also shown that PAH concentration levels significantly exceed the limits. Migdał et al. [41] found the sum of nearly $70 \mu \mathrm{g} / \mathrm{kg}$ in snack stick sausages. However, Migdał [5] identified different levels of contamination with PAHs in smoked meat products. The maximum contamination equalled $34.65 \mu \mathrm{g} / \mathrm{kg}$ and the minimum was $0.15 \mu \mathrm{g} / \mathrm{kg}$. The average sum of the four PAHs in the analysed products was $6.36 \mu \mathrm{g} / \mathrm{kg}$. The studies conducted by German scientists [38, 39] proved that the average 


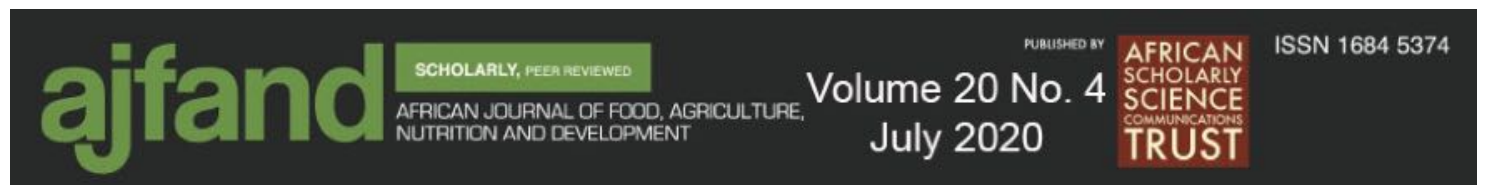

concentration sum of the four PAHs was $3.35 \mu \mathrm{g} / \mathrm{kg}$ in frankfurter sausage and $3.2 \mu \mathrm{g} / \mathrm{kg}$ in salami.

\section{CONCLUSION}

The contamination of "Traditionally smoked sausage" with benzo(a)anthracene, benzo(a)pyrene and benzo(b)fluoranthene is higher in products smoked for 6-7 and 7-8 hours compared to a shorter smoking period. There is no effect of smoking time on chrysin concentration. Nevertheless, due to the high toxicity of this compound, a concentration of around $10 \mu \mathrm{g} / \mathrm{kg}$ can pose a serious threat to consumer safety. The recognized changes in the analyzed sums of PAHs are the result of changes in the concentration of each PAH. In addition, it appears that the sums of the concentrations exceed the limits specified in EU regulations many times. Therefore, the use of a longterm smoking process at high temperatures in the production of "Traditionally smoked sausage" can be a major obstacle to the product being approved. 


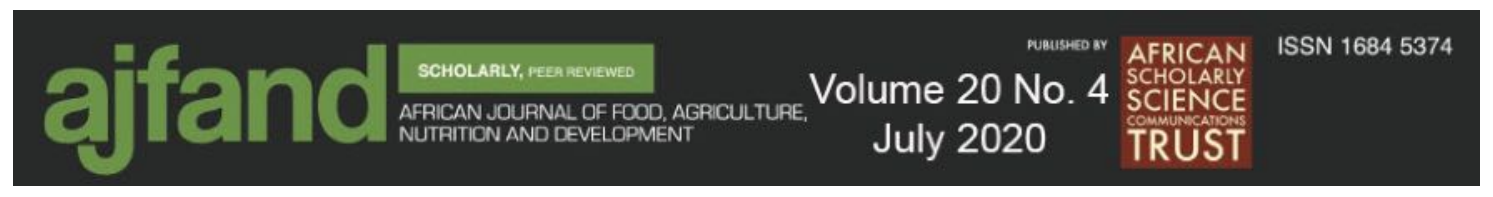

Table 1: Eluent gradient program

\begin{tabular}{|l|l|l|l|}
\hline Time $[\mathbf{m i n}]$ & Acetonitrile & $\mathbf{H}_{\mathbf{2}} \mathbf{O}$ & Ethyl acetate \\
\hline $\mathbf{0}$ & 75 & 25 & 0 \\
\hline $\mathbf{1 5}$ & 75 & 25 & 0 \\
\hline $\mathbf{5 5}$ & 93 & 7 & 0 \\
\hline $\mathbf{5 6}$ & 100 & 0 & 0 \\
\hline $\mathbf{6 0}$ & 100 & 0 & 50 \\
\hline $\mathbf{7 5}$ & 50 & 0 & 0 \\
\hline $\mathbf{8 0}$ & 100 & 0 & 0 \\
\hline $\mathbf{8 5}$ & 75 & 25 & 0 \\
\hline $\mathbf{9 0}$ & 75 & 25 & \\
\hline
\end{tabular}

Table 2: Fluorescence detector program - Waters $2475^{1}$

\begin{tabular}{|c|c|c|c|c|}
\hline \multirow[t]{2}{*}{ Time [min] } & Channel A & Channel B & Channel C & Channel D \\
\hline & \multicolumn{4}{|c|}{ Wavelength: excitation / emission [nm] } \\
\hline $\mathbf{0 , 0}$ & $266 / 408$ & $286 / 408$ & $310 / 357$ & $380 / 406$ \\
\hline 16,0 & - & - & $315 / 510$ & - \\
\hline 22,0 & - & $304 / 433$ & - & - \\
\hline 40,0 & $286 / 420$ & $300 / 500$ & $315 / 422$ & $362 / 408$ \\
\hline 60,0 & $281 / 434$ & $295 / 408$ & - & - \\
\hline
\end{tabular}

Table 3: Percentage changes of the analysed PAH content in the products depending on the increase in the smoking time span

\begin{tabular}{|c|c|c|c|c|c|c|c|c|}
\hline \multirow[t]{2}{*}{ Parameter } & \multirow{2}{*}{$\begin{array}{l}4-5[\mathrm{~h}] \\
{[\mu \mathrm{g} / \mathrm{kg}]}\end{array}$} & \multirow[b]{2}{*}{$\%$} & \multirow{2}{*}{$\begin{array}{l}5-6[\mathrm{~h}] \\
{[\mu \mathrm{g} / \mathrm{kg}]}\end{array}$} & \multirow[b]{2}{*}{$\%$} & \multirow{2}{*}{$\begin{array}{l}6-7[\mathrm{~h}] \\
{[\mu \mathrm{g} / \mathrm{kg}]}\end{array}$} & \multirow[b]{2}{*}{$\%$} & \multirow{2}{*}{$\begin{array}{c}7-8[\mathrm{~h}] \\
{[\mu \mathrm{g} / \mathrm{kg}]}\end{array}$} & \multirow[b]{2}{*}{$\%$} \\
\hline & & & & & & & & \\
\hline Benzo(a)anthracene & $11,17 \mathrm{a}$ & 100 & $12,62 \mathrm{ab}$ & 112,98 & $14,19 \mathrm{~b}$ & 127,04 & $13,24 \mathrm{ab}$ & 118,53 \\
\hline Benzo(a)pyrene & $4,32 \mathrm{a}$ & 100 & $4,15 \mathrm{a}$ & 96,07 & $5,15 b$ & 119,21 & $7,69 \mathrm{c}$ & 178,01 \\
\hline Benzo(b)fluoanthene & $5,32 \mathrm{a}$ & 100 & $4,99 \mathrm{a}$ & 93,80 & $5,50 \mathrm{a}$ & 103,38 & $7,75 b$ & 145,68 \\
\hline Chrysene & 9,85 & 100 & 9,85 & 100 & 10,77 & 109,34 & 10,00 & 101,52 \\
\hline
\end{tabular}

\footnotetext{
${ }^{1}$ Benzo(a)anthracene signal corresponds to wavelength 286/408; benzo(a)pyrene signal corresponds to wavelength $380 / 406$; benzo(b)fluoranthene signal corresponds to wavelength $304 / 433$; chrysene signal corresponds to wavelength $266 / 408$
} 


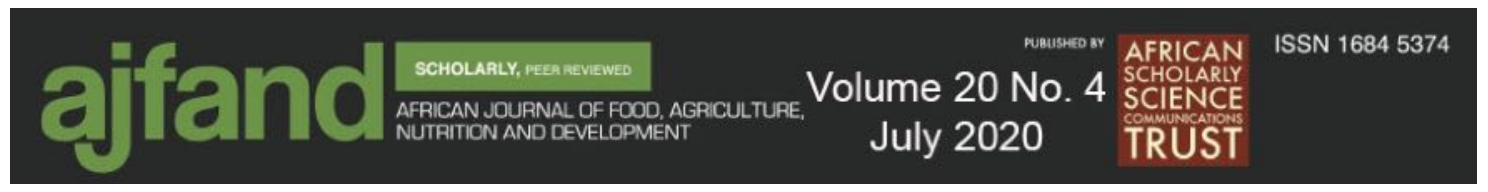

\section{REFERENCES}

1. Ghasemzadeh-Mohammadi V, Mohammadi A, Hashemi M, Khaksar R and P Haratian Microvawe-assisted extraction and dispersive liquid-liquid microextraction followed by gas chromatography-mass spectrometry for isolation and determination of polycyclic aromatic hydrocarbons in smoked fish. $J$. Chromatogra. A, 2012; 1237:30-36.

2. Ledesma $\mathbf{E}$, Rendueles $\mathbf{M}$ and $\mathbf{M}$ Díaz Contamination of meat products during smoking by polycyclic aromatis hydrocarbons: Processes and prevention. Food Control, 2016; 60:64-87.

3. Lorenzo JM, Purriños L, García Fontán MC and D Franco Polycyclic aromatic hydrocarbons (PAHs) in two Spanish traditional smoked sausage varieties: "Androlla" and "Botillo". Meat Sci., 2010; 86:660-664.

4. Rozentāle I, Stumpe-Viksna I, Začs D, Siksna I and A Melngaile Assessment of dietary exposure to polycyclic aromatic hydrocarbons from smoked meat products produced in Latvia. Food Control, 2015; 54:16-22.

5. Migdal W Sterowanie jakością produktów pochodzenia zwierzęcego. Przegląd Hodowlany, 2015; 5:1-8.

6. Kołakowski E Food smoking technology (in Polish). PWRiL, Warszawa, 2012.

7. Migdał W, Dudek R, Kapinos F and W Kluska Wędliny wędzone tradycyjnie zawartość wielopierścieniowych węglowodorów aromatycznych (WWA). In: Właściwości produktów i surowców żywnościowych. Wybrane zagadnienia. Polskie Towarzystwo Technologów Żywności - Oddział Małopolski, 2014; 75-87.

8. Bagnowska A, Mostowski R, Trzessowska A and $\mathbf{L}$ Krala Technical, Technological and Health Safety Aspects Smoking of Meat (in Polish). Acta Scientarum Technica Agraria, 2011; 10:33-40.

9. Li J, Dong H, Han B, Zhu Ch and D Zhang Quantitatively assessing the health risk of exposure to PAHs from intake of smoked meats. Ecotox. Environ. Safe, 2016; 124:91-95.

10. Lee J-G, Kim S-Y, Moon J-S, Kim S-H and DH Kang Effects of grilling procedures on levels of polycyclic aromatic hydrocarbons in grilled meats. Food Chem., 2016; 199:632-638.

11. Fasano E, Yerba-Pimentel I and E Martinez-Carballo Proofing, distribution and levels of carcinogenic polycyclic aromatic hydrocarbons in traditional smoked plant and animal foods. Food Control, 2016; 59:581-590. 


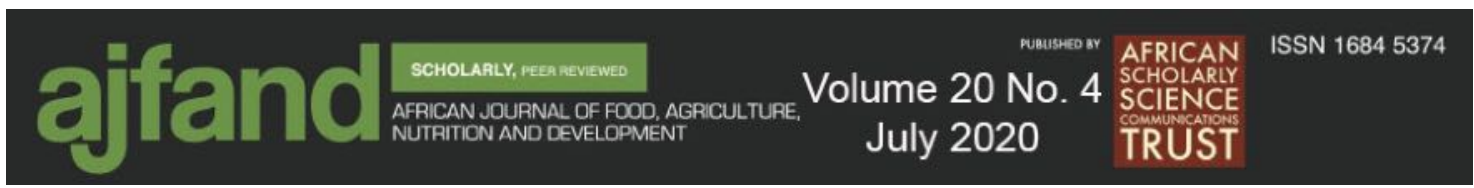

12. Kostyra $\mathbf{E}$ Wood smoke and smoke flavouring preparation-composition, function application (in Polish). Postępy Techniki Przetwórstwa Spożywczego, 2005; 5:4850 .

13. Yang H, Yan R, Chen H, Lee DH and Ch Zhung Characteristics of hemicellulose, cellulose and lignin pyrolysis. Fuel, 2007; 86:1781-1788.

14. Ledesma E, Rendueles M and M Díaz Benzo(a)pyrene penetration on a smoked meat product during smoking time. Food Addit. Contam., A, 2014; 31:1688-1698.

15. Singh L, Varshney JG and $\mathbf{T}$ Agarwal Polycyclic aromatic hydrocarbons formation and occurrence in processed food. Food Chem., 2016; 199:768-781.

16. Parol J, Pietrzak-Fiećko $\mathbf{R}$ and SS Smoczyński Wielopierścieniowe węglowodory aromatyczne (WWA) w wędzonym pstrągu tęczowym (Oncrhynchus Mykiss). Żywność. Nauka. Technologia. Jakość, 2014; 97:125-137.

17. Jägerstad M and K Skog Genotoxicity of heat - processed foods. Mutat. Res., 2005; 574:156-172.

18. Ciemniak A Comparisson of grilling method effects on benzo[a]pyrene contents in chicken meat (in Polish). Żywność. Nauka. Technologia. Jakość, 2007; 52:5461.

19. Sapota A Polycyclic aromatic hydrocarbons (in Polish). Podstawy i Metody Oceny Środowiska Pracy, 2002; 2:179-208.

20. Węgrzyn E, Grzeskiewicz S, Popławska W and BK Glod Modified analytical method for polycyclic aromatic hydrocarbons, using sec for sample preparation and RP-HPLC with fluorescence detection. Application to different food samples. Acta Chromatogr., 2006; 17: 233.

21. Rey-Salgueiro L, Martínez-Carballo E, García-Falcón MS and J SimalGándara Survey of polycyclic aromatic hydrocarbons in canned bivalves and investigation of their potential sources. Food Res. Int., 2009a; 42:983-988.

22. Guo W, He M, Yang Z, Lin C, Quan X and B Men Distribution, partitioning and sources of polycyclic aromatic hydrocarbons in Daliao River water system in dryseason, J Hazard Mater., 2009; 164:1379-1385.

23. Alomirah H, Al-Zenki S, Husain A, Sawaya W, Ahmed N, Gevao B and K Kannan Benzo[a]pyrene and total polycyclic aromatic hydrocarbons (PAHs) levels in vegetable oils and fats do not reflect the occurrence of the eight genotoxic PAHs. Food Addit. Contam., 2010; 27:869-878.

24. Alomirah H, Al-Zenki S, Al-Hooti S, Zaghloul S, Sawaya W, Ahmed N and K Kannan Concentrations and dietary exposure to polycyclic aromatic hydrocarbons (PAHs) from grilled and smoked foods. Food Control, 2011; 22:2028-2035. 


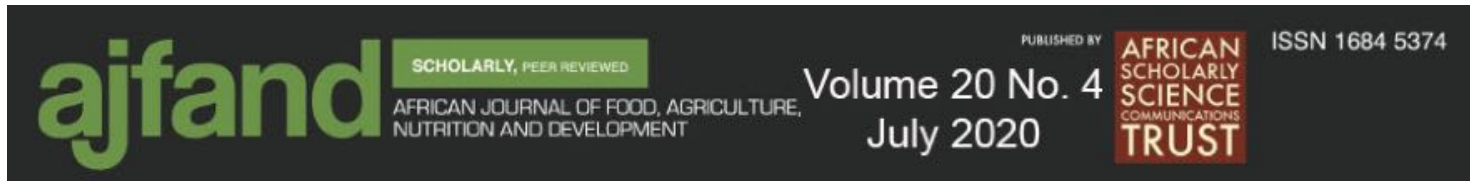

25. Djinovic J, Popovic A and W Jira Polycyclic aromatic hydrocarbons (PAHs) in different types of smoked meat products from Serbia. Meat Sci., 2008; 80:449456.

26. Rey-Salgueiro L, Martínez-Carballo E, García-Falcón MS, GonzálezBarreiro $\mathbf{C}$ and $\mathbf{J}$ Simal-Gándara Occurrence of polycyclic aromatic hydrocarbons and their hydroxylated metabolites in infant foods. Food Chem., 2009b; 115:814-819.

27. Arias AH, Vazquez-Botello A, Tombesi N, Ponce-Vélez G, Freije $\mathbf{H}$ and $\mathbf{J}$ Marcovecchio Presence distribution and origins of polycyclic aromatic hydrocarbons (PAHs) in sediments from Bahía Blanca estuary. Environ. Monit. Assess, 2010; 160:301-314.

28. Yebra-Pimentel I, Fernández-González R, Carballo EM and J Simal-Gándara Searching ingredients polluted by polycyclic aromatic hydrocarbons in feeds due to atmospheric or pyrolytic sources. Food Chem., 2012; 135:2043-2051.

29. Yebra-Pimentel I, Fernández-González R, Martínez-Carballo E and J SimalGándara Optimization of purification processes to remove polycyclic aromatic hydrocarbons (PAHs) in pollute draw fish oils. Sci. Total Environ., 2014; 470:917924.

30. Shrestha B, Anderson TA, Acosta-Martinez V, Payton P and JE CañasCarrell The influence of multiwalled carbon nanotubes on polycyclic aromatic hydrocarbon $(\mathrm{PAH})$ bioavailability and toxicity to soil microbial communities in alfalfa rhizosphere. Ecotox. Environ. Safe., 2015;116:143-149.

31. Pongpiachan $\mathbf{S}$ A preliminary study of using polycyclic aromatic hydro-carbons as chemical tracers for traceability in soybean products. Food Control, 2015; 47:392-400.

32. Norinaga K, Deutschmann O, Saegusa $\mathbf{N}$ and $\mathbf{J}$ I Hayashi Analysis of pyrolysis products from light hydrocarbons and kinetic modelling for growth of polycyclic aromatic hydrocarbons with detailed chemistry. J. Anal. Appl. Pyrolysis, 2009; 86:148-160.

33. Esposito M, Citro A, Marigliano L, Urbani V, Seccia G, Marotta MP and C de Nicola Influence of different smoking techniques on contamination by polycyclic aromatic hydrocarbons in traditional smoked Mozzarella di Bufala Campana. Int. J. Dairy Technol., 2015; 1:97-104.

34. Cirillo T, Milano N and RA Cocchieri Polycyclic aromatic hydrocarbons (PAHs) in traditional smoked dairy products from Campania (Italy). Ital. J. Public Health., 2012; 1-2:51-53.

35. Regulation (EC). No 208/2005 of 4 February 2005 amending Regulation (EC) No $466 / 2001$ as regards polycyclic aromatic hydrocarbons. 


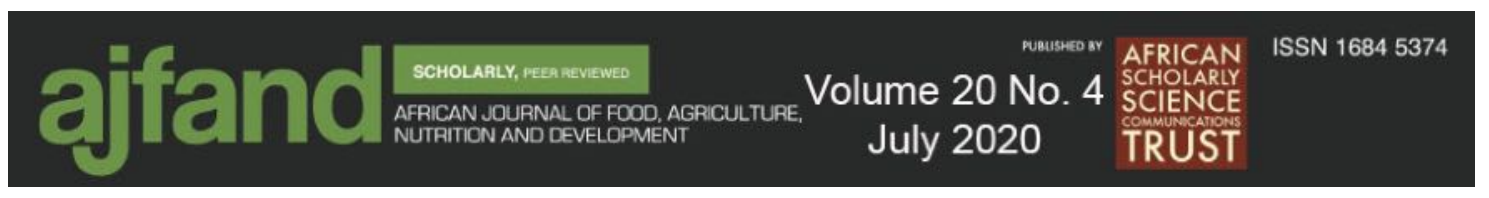

36. Regulation (EC). No 835/2011 of August 19, 2011 amending Regulation (EC) No $1881 / 2006$ on the maximum acceptable level of polycyclic aromatic hydrocarbons content in food products.

37. Regulation (EC). No 1881/2006 of 19 December 2006 setting maximum levels for certain contaminants in foodstuffs.

38. Hitzel A, Pöhlmann M, Hitzel A, Schwägele F, Speer K and W Jira Polycyclic aromatic hydrocarbons $(\mathrm{AH})$ and phenolic substances in meat products smoked with different types of wood and smoking spices. Food Chem., 2013; 139:955962.

39. Pöhlmann M, Hitzel A, Schwägele F, Speer K and W Jira Content of polycyclic aromatic hydrocarbons (PAH) and phenolic substances in Frakfurter-type sausages depending on smoking conditions using glow smoke. Meat Sci., 2012; 90:176-184.

40. Ledesma E, Rendueles $\mathbf{M}$ and $\mathbf{M}$ Díaz Spanish smoked meat products: Benzo(a)pyrene (BaP) contamination and moisture. J. Food Compos. Anal., 2015; 37:87-94.

41. Migdał W, Dudek R, Kapinos F and W Kluska Wędzenie tradycyjne - Punkty krytyczne. Polskie Stowarzyszenie Producentów Wyrobów Wędzonych Tradycyjnie. Kraków-Pilzno 2016. 